\title{
ON SOME HUNGARIAN AND GENERAL ASPECTS OF AN 18TH-CENTURY ROMANIAN GRAMMAR WRITTEN IN LATIN
}

\author{
RÉKA LŐRINCZI \\ Department of Contemporary Hungarian \\ Institute of Hungarian and Finno-Ugric Linguistics \\ Eötvös Loránd University \\ Múzeum körút 4/A \\ $\mathrm{H}-1088$ Budapest \\ Hungary \\ nefelejtsxx@gmail.com
}

\begin{abstract}
This paper deals with issues concerning the general and Hungarian-related history of grammar writing on the basis of the first Latin grammar of the Romanian language recently published in two versions, due to the separate work of two scholars. It emphasises some important ways in which that grammar has a bearing on Romanian literature in the Cyrillic script and explores its essential similarities with the rudimenta of morphology and syntax in Alvares' textbook. It mentions certain recognisable connections with Alvares' and a few other humanistic Latin grammars, medieval language descriptions, and grammars of Hungarian in Latin. The author considers this grammar an important work of Romance philology in the Carpathian Basin, among other reasons, because it was the first to demonstrate, in the relevant literature of the area, the Latin origin of Romanian on the basis of grammatical correspondences - unlike in the Hungarian literature of the period where the same point was merely made on the basis of correspondences within the word stocks of the two languages.
\end{abstract}

Keywords: Romanian Cyrillic script, grammatical regulae, concordance, government, origin of Romanian

1. The aim of this paper is to recapitulate, extend and make more precise the claims I made in Lörinczi (2005a, b) with respect to the grammar mentioned in the title. A reconsideration of those issues seems to be justified by the following two considerations:

(a) The grammar, written in Latin, is the earliest extant description of one of the European vernaculars, Romanian. Published in a printed 
form as late as in 2001, it represents a special area of the history of linguistics in Europe and deserves distinguished attention in and for itself.

(b) Its discussion offers the possibility of casting a glance at certain wider perspectives beyond the history of Romanian grammar writing.

2. The manuscript of the Romanian grammar "Institutiones Lingvae Valachicae sive Grammatica compendio exhibita" (henceforward ILVal), now published in two versions, can be found in the archive of manuscripts of the archiepiscopal library of Kalocsa and has been known among experts for over a hundred years now. Recognising its importance, the eminent philologist János Karácsonyi (1858-1929) called the attention of Ion Siegescu (1873-1931) to it (cf. Nagy 1983, 204; no reference given). The young scholar of Romance philology soon started studying the manuscript. His work was carried on by his successor in the chair of the department of Romanian of Budapest University, the philologist and historiographer Carlo Tagliavini (1903-1982) ${ }^{1}$ (cf. Kese 1999, 159-61; Chivu 2001,10 ), including special focus on aspects of the grammar having to do with the Society of Jesus. The issue was also studied by Béla Nagy (19251995), another (subsequent) professor of the department (see Nagy 1983; 1984).

One of the published transcripts of the grammar was edited by Gheorghe Chivu, professor at Bucharest University, having worked on the manuscript since 1986, with an introduction and notes and accompanied by a Modern Romanian translation by Lucia Wald (Chivu 2001). The other transcript was also published in 2001, by Alin-Mihai Gherman, lecturer at the university of Alba Iulia, another scholar who had spent a long time working on it (Gherman 2001). The latter edition also includes the transcript of a dictionary entitled "Lexicon compendiarium latino-valachicum complectens dictiones ac phrases latinas cum valachica earum interpretatione" whose reference number in the Kalocsa archives differs from that of ILVal by a single digit and the last line of which is followed by "A. M. D. G.". Of course, the difference of opinion between the two publishers, Chivu and Gherman, is an issue that has to be left for Romanian linguists to discuss, especially with respect to their diverging views on the authorship of the manuscript. In particular, Chivu assumes an unknown author for the time being, whereas Gherman attributes both

${ }^{1}$ See, for instance, Tagliavini's Panorama di storia della linguistica, Pàtron, Bologna, 1968.

Acta Linguistica Hungarica 56, 2009 
the grammar and the dictionary to a representative of the Transylvanian School (Şcoala Ardeleană), Grigore Maior (1715-1785).

2.1. The external history of the grammar that some scholars date at 1768 (but that is dated around 1770 by Chivu) can be associated, at least in part, with Nagyvárad/Oradea (Magno Varadinum, Varadinum, Großvardein). On its title page it is dedicated to Xavér Ferenc Rhier (Rier), Abbot of Abasár (diocese of Eger), Canon of Nagyvárad, and Archdeacon of Közép-Szolnok/Solnoc de Mijloc who, according to the Praefatio, was an encourager of the work itself. As the time of Rhier's canonry at Nagyvárad, Chivu gives the years 1762 to 1777 (Chivu 2001, 150 , note 4). On the basis of the historical schematism of the diocese, published in 1896, András Emődi gives the years 1762 to 1779. He also notes that Rhier appointed the library of the cathedral chapter as devisee of his whole collection of books (Emődi 2002, xvi, xxi; for more data on Rhier, cf. Bunyitay-Málnási 1935, 351, 480-1).

Concerning the way the grammar found its way to Kalocsa, the literature assumes that it may have been connected with the 1776 appointment of Ádám Patachich (1717-1784), formerly Bishop of Nagyvárad, as Archbishop of Kalocsa (Chivu 2001, 10, note 2). In view of the above data concerning Rhier, it might be asked why the grammar should have been added to Patachich's library prior to Rhier's death in 1779. It is even imaginable that, for some reason, the grammar was never handed over to Rhier. Perhaps the author, seeing the poor legibility of the text due to the inferior paper quality (see the facsimile excerpts on pp. 27-8 of the published version), may have planned the preparation of another copy, more convenient to use. Indeed, assuming that this important work did actually get into the possession of Rhier, it remains to be explained why it was left unpublished at the time. This explanation is especially needed because one of Rhier's tasks was exactly to be concerned with the community of Greek-Catholic Romanians (cf. Bunyitai-Málnási 1935, loc.cit.). On the other hand, if the work was indeed related to the Society of Jesus, it can easily be assumed that it got to Kalocsa directly from the author or from his posthumous legacy. The fact that several Jesuit scholars enjoyed the friendship and support of Patachich, a man of erudition, not only before the dissolution of the order in 1773 but also afterwards, can be documented from several sources. ${ }^{2}$

\footnotetext{
${ }^{2}$ For instance, the friendship of Patachich and Pray is documented by Lischerong
} 
2.2. Of the issues of content surrounding ILVal, one that has great significance is that it represents its data in Romanian Cyrillic script, as befits the older main variety of the Romanian literature of the time, and its references are also made to Cyrillic sources "quae occurrunt in libris, tum in scriptura" (6-7/56- -here and in what follows, figures before the slash refer to page numbers in the manuscript, while those after the slash indicate the page number in Chivu's published version). The relevant literature considers the Catechism of Nagyszeben/Sibiu (1544) to be the first printed product of that Romanian Cyrillic literature (cf. Borsa et al. 1971, 59; on the history of Romanian literature in Cyrillic letters, definitely see Vîrtosu 1968). The author of the grammar, thus, for some reason ignored Romanian literature in Latin script that can be amply documented for the 18th century. That literature had been represented, also from the 16th century onwards, by a Protestant, and then a Catholic, line of development. With respect to issues of Latin-letter Romanian literature and the missionary work by Jesuits among Romanians, cf. Mălinaş (1997), Periş (1998), Molnár (1999), and from Romance philology circles in Hungary, L. Nagy (2000).

2.3. A further problem coming from the relevant literature so far concerns the grammar's forerunners (if any). The answers are of two types.

2.3.1. One of them is B. Nagy's answer according to which the association of ILVal to any earlier work can be excluded: "La composition est individuelle, et l'on peut démontrer qu'elle n'est liée à aucune école" (Nagy 1983, 217); "Its structure is unique, and demonstrably not linked to any school" (Nagy 1984, 419-emphasis in the [Hungarian] original). However, that claim can be accepted as convincing with respect to some of the chapters only.

Thus, it was presumably based on the author's own ideas and solutions, with no immediate forerunners, that the section entitled "De literis,

(1937, passim). Lischerong also notes that until 1781 Patachich's librarian in Kalocsa was a Jesuit, the Italian Jacob Mariosa [Marioso?]. See further István Schönvisner's manuscript "Vita Georgii Pray", which mentions a poem entitled "Propemticon" among Pray's writings, with the following explanation: "Jacobo Mariosa Jtaliam repetenti. Colocae MDCCLXXXI. in 8. /Hic fuit Archiepiscopi Colocensis Adami L. B. Patachich Bibliothecarius, Presbyter quondam S. J. ex provincia Neapolitana, Poeta, orator, et Hiftoricus, Prayo amicus" (National Széchényi Library, Fol. Lat. 3: 8 -emphasis as in the original). 
earumque proprietatibus" (the first section of the first part) was written. It contains the sound correspondences of the Romanian Cyrillic letters, listed in an order differing from the Latin alphabet (for the sake of typographical convenience, the Romanian Cyrillic letters of the published version will be represented by regular (Russian) Cyrillic letters in this paper). ILVal being important for Hungarology in more respects than one, the Hungarian connection in this part is that in giving the sound correspondences of some of the letters it is based on contemporary Hungarian letter-sound correspondences, in particular, what are known as the Catholic ones (from the relevant literature on the history of Hungarian orthography, cf. Kniezsa 1952, 15-6). Thus, the discussion is framed against the backdrop of Hungarian as an ambient language. The correspondences in question are: $\amalg$ ц- $\mathrm{Cz} ; \mathrm{\Psi}$ ч-Csh, csh; $\amalg-\mathrm{S}, \mathrm{s}$ durum; C c-S, s lene; $\amalg$ ! - Zs vel ds $(2-3 / 52)$. About the distinction between $s$ durum and $s$ lene, see a paper by János Balázs (1914-1989) that inevitably refers to Sylvester, too (Balázs 1958, esp. 260-1, 277, 280-1). The issue has also been discussed by O. András Vértes (1911-1997) (Vértes 1980, 34). ${ }^{3}$ The correspondences listed in ILVal are surely worth noting because-as Vértes also suggests - it has unfortunately never occurred to anyone to survey the letter-to-sound correspondences of early Romanian documents (be they written in Cyrillic or Latin letters) from the point of view of the history of Hungarian sound representation or phonology. (With respect to Hungarian texts produced by Moldavian Csángó subjects schooled in today's Romanian orthography, however, cf. Mátai 1992; Lörinczi 1995.)

Another section with no predecessor is that entitled "De interpunctionibus". In its $\S 5$, the following remark can be read on the comparison of Latin and Cyrillic writing habits: "Illud peculiare Valachis est, quod loco notae (\&с) significandae, hoc vocabulum и прочй expresse

${ }^{3}$ He writes with respect to Komáromi Csipkés: "[...] he read sigma as $\check{s}$, that is, according to the pronunciation rules of Latin in Hungary, rather than those of Classical Latin or Greek. This reading of sigma as $\check{s}$ is especially interesting because one of the aims of his work was to teach non-Hungarians, especially Transdanubian Germans, to speak Hungarian [...]. Thus the question arises why he explained the Hungarian sound value of $s$ in terms of the value of Greek sigma and Latin $s$ in their Hungarian pronunciation. He must have been aware that $\check{s}$ as a value of Latin $s$ was not totally unfamiliar for speakers of other languages living next to Hungarians [cf. Rom. şcoală $<$ scola-R.L.]. However, the question is far from settled given that he intended his grammar to be used by foreigners, too ('exteras nationes Sclavicos, Polonos, Bohemos, Valachos, Germanos, Thraces, Croatas, Rutenos, [...]': CorpGr. [Toldy 1866], 338)". 
ponatur" (7/58 - emboldening follows the published version here and in subsequent quotations). On the other hand, Chivu points out in endnote 26 that the claim in ILVal that punctuation marks are used in Romanian just like they are in Latin is wrong. As is known, such "identity" is not evident not only in Romanian but in other early Cyrillic texts, either.

The fifth Caput is also a part that is closely connected with the literacy of Eastern Christianity. Its §6, entitled "De Apostropho" (32-3/92) begins like this: "Apostrophi notio est eadem quae apud Graecos, qui apostrophus Valachos frequens est. Fit autem, cum duae particulae, aut pronomina in una voce sic coalescunt, uter priori particula, aut pronomine aliquae literae omittantur, ut [...] Quandoque plures voculae [emphasis mine: R.L.] quasi in unam contrahuntur [...]". (On the particula/vocula issue, see below.) The grammar uses the term apostrophe in a sense like 'apocope', a usage that can be traced back to Priscian and beyond, rather than as the name of a punctuation mark as it is normally used today (cf. Chivu 2001, note 83-the sentence by St. Isidore [I: XIX/(8)] that is merely referred to in this note is "Apostrophus pars item circuli dextra et ad summam litteram adposita, fit ita: ), qua nota deesse ostenditur in sermone ultima vocalis, ut 'tribunal' pro 'tribunale' "(emphasis mine: R.L.). Thus, the grammar uses the term apostrophe to refer to an elision-type detractive process (regularly used in present-day Romanian, too) that it illustrates by mi-au zis [< mie 'to me' au zis 'they said'], among other examples (32-3/92 - cf. also B. Nagy 1983, 211; as a similar phenomenon in French, see e.g., il m'a dit 'he said to me', etc.).

2.3.2. Researchers who disagree with Béla Nagy with respect to (the lack of) forerunners, that is, people who try to find external models, are probably right especially with respect to the morphological and syntactic portions of the grammar. Despite their various suggestions as to the possible forerunners of ILVal, the issue can still be considered as unresolved. It has been suggested, in particular, that ILVal might be linked to a grammar by Pál Kövesdi (?-1682), "Elementa Linguae Hungaricae" (1686), but then the suggestion was soon discarded. Chivu justifies the dismissal (which is, by the way, correct) by saying that Kövesdi emphasises the differences between Hungarian and Latin. He begins his syntax with the following subtitle: "DE SYNTAXI, /in quantum Conftructio Hungarica difcedit a Latina" (Toldy 1866, 576). His Elementa may have been brought into the discourse on ILVal because it discusses syntax in terms of regulae. 
It has to be added at once that in the published version (Toldy 1866, 549-84) the word Regulae occurs only once, on page 576, as a common superordinate title of ten main theses on syntax that are just identified by numbering (on the presence of regula-based grammars in the antiquity, their early medieval descendants and their characteristics, see Law 1986).

As opposed to the foregoing, Chivu is quite right in assuming the effect of some other grammar. In trying to find it, he starts searching in Volume 2 of Szabó (1879-1898) and in that of Doina Nägler's Catalogue of Transylvanica (Nägler 1982). He decides to ignore the grammars that figure in those books as being in use in the 18th century, notably those by Philip Melanchton (1497-1560), Johann Heinrich Alsted (1558-1638), and Johannes Rhenius (1574-1639). It has to be noted though that the situation is somewhat different with Rhenius' 1736 edition (published in Hungary), containing bohemica data, too. Its title, referring to its being regula-based, too, is "Compendium Latinae Grammaticae [...] Adjunctae fubindè Regulae Notaeque variae, hactenùs defideratae [...]". On Magister Rhenius of Leipzig and on the relevance of his grammar published in 1610 to the history of grammar writing, cf. Borsa et al. (1971, 2327); see furthermore a recent paper by Balázs Sára on a previously not discussed Latin grammar from the 16th century (Sára 1999-2001, 163, 166).

Chivu suggests and then discards the idea that a grammar by Mihály Ajtai Abód (1704-1776) might be a forerunner (Chivu 2001, 37, 40). This short $(5+116+3$ pages) Latin grammar containing Hungarian examples, too, is entitled "Grammatica Latina Methodo Nova \& artificiofa In Ufum Inlustris Gymnalii Bethleniani adornata" (1744). (On Ajtai, born in Szárazajta/Aita Seacă, working for some time as a court-chaplain of Kata Bethlen, cf. Éder 1978, 13-8.) This textbook was published several times, and must have been revised again and again, as can be inferred from one of its editions that contains additional German examples (National Széchényi Library, L. Lat. 306).

Of course, browsing Ajtai's grammar, it is quite easy to discover the use of regulae, a feature that is taken by Chivu as a basic similarity. Since, however, these do not quite correspond to those in ILVal, Chivu concludes that the search for forerunners has to be continued in the direction of works similar to Ajtai's. It is difficult to imagine, anyway, that a book published in Nagyszeben (Sibiu), written by a teacher at the Reformed secondary school of Nagyenyed/Aiud (Straßburg) and recommended by its author to the youths studying there should have been in use by Jesuits. 
2.3.3. Among possible forerunners, both Gherman and Chivu suggest the idea of a connection with Alvares. The latter mentions the fact that various editions of Alvares were in use in Austrian and Transylvanian schools. However, referring to reasons of length and structure, he finally discards the possibility of linking ILVal to these (Chivu 2001, 36).

Looking into the Alvares editions available in our libraries and the related literature, the following points may be mentioned as especially important with respect to ILVal.

The three-part textbook by the Portuguese Jesuit, Emmanuel Alvares (1526-1582), "Institutionum Grammaticarum libri III" was first published in Lisbon in 1572. Despite the more than 200-year distance, a connection between ILVal and Alvares is still possible because, in accordance with the recommendation of Ratio studiorum (completed in 1586, modified in 1591, endorsed in 1599 and later updated), Alvares was the textbook used in Jesuit schools of Europe and also other continents until the mid-1800s, except in French Canada, in the provinces of France and Flanders. The latter asked (and were granted) permission to use the books by Ioannes Despauterius (1460-1520) (cf. also Springhetti 19611962; Lukács 1986, 363; 1992, 368, 369, 602; Bauer 1998). The influence of Despauterius, surviving in the somewhat later Ramus-grammars and also in versions of "Grammaire Générale et Raisonnée", may also be connected to the fact that some generations there were raised on his books rather than those by Alvares. In view of the points to be made below, it is worth noting that that influence is to be taken to include some portions taken over from "Doctrinale puerorum" by the pre-humanism scholar Alexander de Villa Dei (1170-1250), a work otherwise criticised by Despauterius.

As can be concluded from Springhetti (1961-1962), a paper not quite free of anachronisms, at least 530 editions of the textbook by Alvares were published and were used in Jesuit schools of all the five continents. The explanation of its remaining in use for almost three hundred years, beyond being recommended by Ratio studiorum, may be that it was a textbook discussing morphology, syntax, and (metrics and) stylistics separately and at length (in Libri I, II, and III), hence one that gave a comprehensive grammar course in a unified conceptual framework, methodologically carefully edited and convenient to use. With respect to its general use in Catholic schools in Hungary, cf. Mészáros (1981), Hets (1938); on its use by the Nagyvárad Jesuits, see e.g., Cséplő (1894; 1895). 
Another important point is that Alvares' book did not only appear in a number of revised, partial, and abridged editions but in other versions, too. These are of the following types. (1) Adaptations giving the examples (paradigms, etc.) in various languages (beside Latin). Some of these use a single additional language (English, Flemish, French, Croatian, Japanese, Chinese, Hungarian, German, Italian, Spanish, etc.), most of them, however, use two or more (often French and German, less often Flemish with German, French with Greek, Japanese with Portuguese, Polish with German, Hungarian with German, German with Czech or Slovakian, Italian with German).-(2) There are translations (English, German) or adaptations (English, French, German) of one of the three parts of the book.-(3) Perhaps not uninterestingly, there are even instances of the model of Alvares being used for the description of a vernacular. The literature mentions the following as a case of this type: "Observations pour la Langue Françoise et sur l'Orthographe tant Françoise que Latine [...]." (1758) — cf. Sommervogel (1890-1909) under Alvares; Springhetti (1961-1962). With respect to Alvares-style descriptions of South-American Indian languages, cf. Zwartjes (2002).

I have personally consulted two rudimenta-type editions published by the Jesuit academy of Kolozsvár/Cluj, hence ones that are presumably "closer" to the author of the ILVal (with respect to the history of the academy between 1579 and 1604, and to later literature on its existence, cf. Jakó 1991). One is an edition published in 1729 on [5+137] pages, the other one is from 1768, contains Hungarian and German equivalents of the example words and amounts to $136+20+32$ pages (cf. Alvares 1729; 1768). A mere glance at them reveals that they are (partly) formulated in regulae (in some editions called praeceptum) like humanistic grammars used to be.

2.3.3.1. The first task of comparison with the Alvares editions referred to obviously involves a study of the morphological (including part-ofspeech classification) sections of ILVal.

The first four paragraphs of the morphological chapter of ILVal, beginning with its second Caput, discuss nouns and adjectives. The caputs of nomina (that are internally well-organised, introducing adjectives, their comparison, and agreement as well) are followed by pronominal and then verbal ones. This is similar to grammatical treatises by Aelius Donatus (around 350), St Isidore (565?-636), Antonio Nebrija (1444-1522), Aldus Manutius (1450-1510), Thomas Linacre (around 1460-1524), Despau- 
terius, Sylvius Jacobus Ambianus (also known as d'Amiens Dubois, 14891555), Philip Melanchthon (1497-1560), Louis Meigret (1500-around 1558), Petrus Ramus (Pierre Ramée, 1515-1572), and Alvares; similar order can be found in Grammaire Générale et Raisonnée (Arnauld-Lancelot 1676/1966, 30-53).

As opposed to this nomen-pronomen-verbum order going back to the Stoics and Dionysius Thrax (around 170-around 90 B.C.), Priscian (around 500 A.D.) has the order nomen-verbum-participium-pronomen. The followers of that alternative order include Guarino Veronese (1374-1460), Laurenzio Valla (1407-1457), Nicolaus Perotti (1429-1480), Giovanni Verulano Sulpitius (1445/1450-1513), Julius Caesar Scaliger (1484-1558), Franciscus Brocensis Sanctius (also known as Sánchez de las Brozas, 1523-1600), Gaspar Scioppius (1576-1649) and others (see Cytowska 1968, 85-101, discussing the order of parts of speech from Palaemon to Alvarus and Zaborowski).

We have to specially mention that, in discussing nominal declension and some other issues, the ILVal talks about particles, too. By particulae, it means prepositions of the accusative and of the ablative, the semi-free accompanying morphemes of the genitive $a$, al, ale, ai, as well as that of the dative, lui (cf. French de, du, des, au, etc., English of, for, etc.). But the same word particula is also used for the $o$ of the vocative. (The interjection $o$ was treated by Dionysius Thrax and some later scholars as an article-like vocative marker, cf. Lallot 1998, 61, 194; Schenkeveld 1988.). At one point of the syntax $(75 / 146)$, the ILVal writes this: "Particula $\chi є и$ heu Dat[ivus] jungitur ut [...]: heu mihi misero!" Similarly, particulae crop up in $\S \S 2-3$ entitled "De comparatione Adjectivorum" of the fourth Caput (22-3/78-81) saying that "comparativo gradui praeponitur particula май, magis, superlativo ши май maxime". Superlative particles of the type prea, foarte (to cite only Latin-letter equivalents here) are also mentioned.

Priscian's discussion of the word class referred to as particulae, going back in some respects to Aristotle and having an inventory continually changing over the centuries (not to mention the 'suffix'-type meaning of the term) was followed by a longer break in the Middle Ages. In the humanistic grammars, however, the authors' attention was directed to the "particle group" again. The use of this term in ILVal, then, is either directly due to the Greek forerunners or shows the author's familiarity with humanistic descriptive practice that partly transmitted, partly surpassed those ancient models. 
Humanistic descriptions of Latin involving particles are as follows: 1580: Godescalcus Steuvechius [Steewech] (around 1556-around 1599): "De particulis linguae Latinae liber unus"; 1587: in a wider perspective involving matters of principle, too: Sanctius' "Minerva seu de Causis Linguae Latinae"; 1588: Matthaeus Devarius (around 1505-1581): "Tractatus de graecae linguae particulis" - the attitude of this book, and perhaps even its being written in the first place may have been influenced by Devarius' experience in the contrastive observation of languages gained during his former translator's activities (with respect to his having translated the documents of the Council of Trent into Greek and to later editions of his grammar, cf. Landgraf 1903, 54); 1598: Orazio Torsellino (Horatius Tursellinus, 1545-1599): "De particulis Latinae orationis"; ${ }^{4}$ 1637: Roland Ogier (1588-1641):: "Inventaire des particules françoise, et esclairissement de leurs divers usage, reduits au parallele de la langue latine"; 1666: François-Antoine Pomey (1618-1673): "Les Particules françoises, méthodiquement exprimées en latin, avec un recueil de celles qui ne souffrent point de méthode, rangée [sic! — cf. Colombat 1999, 85] par ordre alphabétique"; 1695: Robert Saugé [Saulger] S.I. (1637-1709): "Les Particules de la langue latine, avec ses réflexions mises en ordre"; 1769: Henricus Hoogeveen: "Doctrina particularum linguae graecae" (published also in epitomes by Christianus Godofred Schütz: Leipzig, $1806^{2}$ - - on all these, cf. Landgraf (1903).

It can be assumed that 18th-century school grammars discuss the group of word classes concerned due to the renewed interest in particles (even the Encyclopédie contained an entry on particles).

In the literature of Hungary (and its neighbourhood), it is in János Sylvester's (around 1504-after 1551) work that particles begin to be men-

${ }^{4}$ On later revisions of Tursellinus' De particulis cf. Landgraf $(1903,54)$. He is also known to have revised Alvares' grammar (Emmanuelis/ Alvari/ E Societate Jesu/ De Institutione grammatica/ libri tres,/ olim/ Ab Horatio Tursellino/ ejusdem Societatis/ in compendium redacti,/ hac editione restituti,/ mendis innumeris sublatis./ Venetiis,/ MDCCLVIII./ Ex Typographia Remondiniana./ Superiorum permissu, ac privilegio: Library of the Hungarian Academy of Sciences 550.813). With respect to the presence of his linguistic works in Hungary, cf. De particulis [...]: Buda-Nagyszombat, 1777: National Széchényi Library 261.483; Kalocsa, 1777 or 1778: National Széchényi Library 261.386; Nagyszombat, 1781: National Széchényi Library 278.013. On his further reception in Hungary see e.g., Horatius Tursellinus: Gemma latinae [...] rhetorica Cassoviensi selectae. Tyrnaviae, 1737 (Library of the Hungarian Academy of Sciences, 522560).

${ }^{5}$ My thanks must go to Katalin Kron (Library of the Hungarian Academy of Sciences) for excavating the data on Ogier. 
tioned in 1536, that is, well before Steuvechius (1580). However, they are mentioned with the remark that Hungarian has no such things (see Toldy 1866, 72). It is important to note that in Sanctius' grammar-instead of the usual sequential discussion of the traditional eight parts of speech - we find the classification nomen-verbum (Priscian's order)particulae (on this, and part of the foregoing, cf. Schäffer-Priess 2000, 130-43). This three-part classification can be found in "Hungaria Illustrata" by György Komáromi Csipkés (1628-1678) published in 1655 (Toldy 1866, 331-402: Liber I., II., III.: De nomine, De verbo, De particulis) and in "Institutiones" by Sámuel Fejérvári (?1721-1781) (ibid. 103-22; cf. Lőrinczi 1998, 208-32). By contrast, Albert Szenczi Molnár (1574-1639) proposes a four-part classification nomen-pronomenverbum (Donatus' order)-particulae. In his "Novae Grammaticae..." (1610) the chapters on nominals, pronominals, and verbs are followed by Caput XXIX entitled "De vocibus sine numero, vel particulis indeclinabilibus" (Toldy 1866, 239-53).

With respect to the theoretical and applied-lingusitics events concerning the introduction and discussion of this part of speech, Bernard Colombat is right in saying this: "Les 'traités des particules' sont également très rapidement non seulement traduits, mais aussi adaptés, pour permettre de traiter également, puis essentiellement, les petits mots de la langue source. Mais le phénomène le plus important est sans doute la floraison des méthodes ouvertement translinguistiques (emphasis mine: R.L.) à partir des années 1650" (Colombat 1999, 558; cf. ibid. 77-93: "Rudiments, traités des particules et méthodes de thème" and "La question de la particule"; and 717ff). Concerning the issues raised by ILVal with respect to particles, deserving a careful analysis, see also Coseriu (1980); Schenkeveld (1988); and Dascal (1990).

The first section of Caputs VI-X, dealing with verbs, is entitled "De verbo substantivo sum" (33-6/92-6) and presents the relevant Romanian paradigm, too. Concerning the history of the copula being discussed as distinct from other verbs, cf. the detailed analysis by Schäffer-Priess (2000, 194-204; 229-35), based partly on work by Viggo Brøndal (18871942). She tells us, touching on issues of the history of terminology, that the Latin verbum substantivum sum is discussed before all other verbs especially by humanistic grammars, as a continuation of heterogeneous considerations going back to Aristotle, Priscian, and medieval scholars. 
The verbum substantivum is given special treatment in Alvares' books, too. Its differentiation from other verbs can also be seen in Hungarian grammars written in areas geographically closer to ILVal. Thus, "Conjugatio Verbi Léfzek Fio" and "Conjugatio Verbi Vagyok Sum" are discussed separately, after the paradigms of other verbs, by the Jesuit Pál Pereszlényi (1631-1689) (Toldy 1866, 501-3, 503-6). Similarly, Komáromi Csipkés tackles the copula after the paradigms of other verbs (ibid. 385). Szenczi Molnár introduces it among verbs of irregular conjugation (ibid. 205-6). In his morphology, Pál Kövesdi (ibid. 572-4, 578) gives partial paradigms of two irregular verbs, megyek 'I go' and vagyok 'I am', whereas in his syntax, he mentions the verbum substantivum in the section on possessive constructions. Fejérvári, as far as I know, is the first in the history of Hungarian grammar writing to discuss the paradigm of lesz 'will be' in the group represented by hisz 'believe', visz 'carry' (Lörinczi 1998, 91-4). He also employs the term verbum substantivum. Once as a name for nominally used vagyon 'what one has', nincsen 'what one has not', and then as a term for what is called copula today. Cf. 125/18-19 (the number before the slash means page number here, and the number after the slash stands for the serial number; what appears in red ink in the manuscript is represented by emboldening in the published version as well as here): "Regula. 1.: [...] Verbo Subftantivo Vagyon et Vocabula: nintfen cum materia- /liter ponuntur: Jobb a vagyon a nintfennél" ['It is better to have than not to have']; 126/16-23: "Regula 2.: Cum Nominativus cum Suo Praedicato ponitur, et jungitur /mediante Substantivo Verb $^{6}$ Eft Vagyon, Vagynak, Vagyon et /Vagynak, Saepe omittuntur [...]". Without its complete paradigm being provided, the term verbum substantivum is also used by Kövesdi (cf. Toldy 1866, 578).

I consider it a unique feature, and therefore worth our special attention (unless I am simply unaware of possible parallels) that ILVal classifies certain auxiliaries such as the semi-free future morpheme voi, vei 'I will, you will' etc. among particles: "Has particulas eleganter postponi solere verbis" (40/102). One of its notes on conjugation, with respect to the optative paradigm involving de as, de ai etc., says this: "Praedictas particulas in sequentes contrahi posse, ut [...] [дяаш, дяай $]$ " (40/102). With respect to the structure of the optative future, we read "[...] cui solum particula кынд ... praeponitur" (42/104; with respect to further particles of the conjugation system, cf. ibid.). On the "Alvaristic" modal

\footnotetext{
${ }^{6}$ In Fejérvári's autograph: Verbo Substantivo.
} 
system of the verb see Zwartjes (2002, 42-5). For some reason, ILVal does not include discussions of participles and other parts of speech of Romanian that might have been expected to follow the part on verbs.

Instead of further textual remarks, consider the following table of similarities and differences between Alvares and ILVal (Table 1). For purposes of the table, I have used the 1768 Kolozsvár edition (Alvares 1768). Of course, the differences shown by the table may be just as informative as the similarities.

Table 1

\begin{tabular}{|c|c|}
\hline Alvares (1768), Liber I. & ILVal. \\
\hline & $\begin{array}{l}\text { II. Caput Secundum: De nominibus } \\
\text { substantivis } \\
\text { § Primus De Accidentibus Nominum } \\
\S 2 \text {-dus De particulis Nominibus adjici } \\
\text { solitis }\end{array}$ \\
\hline \multirow[t]{2}{*}{$\begin{array}{l}\text { pp. 1-8: Prima nominum Declinatio. } \\
\text { Secunda Declinatio } \\
\text { Tertia Declinatio } \\
\text { Quarta Declinatio } \\
\text { Quinta Declinatio }\end{array}$} & $\begin{array}{l}\S 3 \text {-tius De Prima Declinatione } \\
\S 4 \text {-tus Paradigma Singularis Numeri } \\
\S 5 \text {-tus Paradigma Pluralis Numeri } \\
\S 6 \text {-tus De Secunda Declinatione } \\
\S 7 \text {-timus De Numero Plurali } \\
\S 8 \text {-tavus De Indeclinabilibus }\end{array}$ \\
\hline & $\begin{array}{l}\text { Caput Tertium } \\
\S 1 \text {-mus De mutatione substantivorum } \\
\S 2 \text {-dus De Formatione Diminutivorum } \\
\S 3 \text {-tius De Nominibus Defectivis } \\
\S 4 \text {-tus De Generibus Nominum } \\
\end{array}$ \\
\hline \multirow[t]{2}{*}{$\begin{array}{l}\text { pp. 9-14: De nominum adjectivorum } \\
\text { declinationibus }\end{array}$} & $\begin{array}{l}\text { Caput Quartum: De Nominibus } \\
\text { Adejctivis }\end{array}$ \\
\hline & $\begin{array}{l}\S 1 \text {-mus De mutatione Adjectivi } \\
\text { masculini in foemininum }\end{array}$ \\
\hline pp. 12-22: Modus comparandi & $\begin{array}{l}\S \text { 2-dus De comparatione Adjectivorum } \\
\S 3 \text {-tius Paradigmata Comparationum } \\
\S \text { 4-tus De Concordantia adjectivi cum } \\
\text { substantivo }\end{array}$ \\
\hline \multicolumn{2}{|l|}{ pp. 22-3: Nomina Anomala } \\
\hline & Caput Quintum: De Pronomine \\
\hline $\begin{array}{l}\text { pp. 22-7: De pronominum Primitivorum } \\
\text { Declinatione: (ego, nos, tu, vos, sui) }\end{array}$ & $\begin{array}{l}\S 1 \text {-mus Paradigma Pronominum Ego, } \\
\text { Tu } \\
\S 2 \text {-dus Paradigma pronominum } \\
\text { Demonstrativorum } \\
\S 3 \text {-tius Paradigma Pronominum } \\
\text { Possessivorum }\end{array}$ \\
\hline
\end{tabular}

Acta Linguistica Hungarica 56, 2009 


\begin{tabular}{|c|c|}
\hline Alvares (1768), Liber I. & ILVal. \\
\hline $\begin{array}{l}\text { pp. 27-31: De pronominorum } \\
\text { derivativorum declinatione (meus, Tuus, } \\
\text { etc.) }\end{array}$ & \\
\hline \multirow[t]{2}{*}{$\begin{array}{l}\text { Provocabulum, five Nomen Relativum, } \\
\text { Qui, Quae, Quod } \\
\text { Compolita ex Provocabulo Quis, cum } \\
\text { praecedit. Quifnam, quaenam, quodnam, } \\
\text { vel quidnam } \\
\text { Compolita ex Quis, cum fequitur. } \\
\text { Aliquis, aliqua, aliquod, vel aliquid, } \\
\text { alicujus, etc. } \\
\text { Compolita ex Provocabulo Qui } \\
\text { Quicunque [...] }\end{array}$} & \\
\hline & $\begin{array}{l}\S 4 \text {-tus De Pronominibus interrogativis } \\
\S 5 \text {-tus De Reciprocis } \\
\S 6 \text {-tus De Apostropho }\end{array}$ \\
\hline \multicolumn{2}{|l|}{ pp. 31-120: De verborum conjugatione } \\
\hline $\begin{array}{l}\text { De Verbi Subftantivi Declinatione. Sum } \\
{[\ldots]}\end{array}$ & Caput sextum: De Verbo Sustantivo sum \\
\hline \multirow[t]{2}{*}{$\begin{array}{l}\text { Prima Conjugatio (passive right after } \\
\text { active, too) } \\
\text { II. Conjugatio [... . III. Conjugatio [... } \\
\text { IV. Conjugatio }\end{array}$} & $\begin{array}{l}\text { Caput septimum: De verborum } \\
\text { Conjugatione }\end{array}$ \\
\hline & $\begin{array}{l}\text { Caput Octavum. De Verbis Passivis } \\
\text { Caput nonum: De Verbis Deponentibus }\end{array}$ \\
\hline \multicolumn{2}{|l|}{$\begin{array}{l}\text { De verbis anomalis: compositis e Verbo } \\
\text { Sum, possum, etc. }\end{array}$} \\
\hline $\begin{array}{l}\text { pp. 117-20: De verborum impersonalium } \\
\text { Declinatione }\end{array}$ & $\begin{array}{l}\text { Caput Decimum: De verbis } \\
\text { Impersonalibus } \\
\S 1 \text {-mus Conjugatio Impersonalium } \\
\text { Activae vocis } \\
\S 2 \text {-dus Conjugatio Impersonalium } \\
\text { Passivae Vocis } \\
\S 3 \text {-tius De Supplemento Verborum }\end{array}$ \\
\hline
\end{tabular}

2.3.3.2. Turning to the syntactic part, although Chivu's introduction does not state this, it is certainly worth our attention that Ajtai's grammar (that Chivu does mention) and ILVal are similar not only in their visual structure and in the use of regulae but also in the contents of the individual regulae. Thus, in the fact that-similarly to the usually distinct two parts of humanistic grammars - ILVal also gives the rules of concordance (congruence) and those of government (rectio) in two notice- 
ably distinct groups (I-VII and VIII-XXII). On humanistic grammars in this respect, cf. Colombat (1999, 382-5): "L'installation de l'opposition entre concordance et régime"; (ibid. 385-94): "La victoire sur la modèle concurrant: transitivité /intransitivité"; on the concordance issue, also 401-26; see further Schäffer-Priess (2000, 246-52).

In ILVal, within concordance rules, regulae I and III discuss the obligatory agreement of the nominative noun and the predicate (verbal as well as copular) in terms of number and person. Of course, referring to nominative noun ('subject') and verbum is a matter of opinion. Alvares, and before him Guarino Veronese, also apply a nominative + verb account (which can be traced back to certain attested medieval forerunners), as opposed to the suppositum-appositum approach of most medieval grammars (going back to the Aristotelian hypokeimenon - kategorema duality). Neither this difference, nor the use of the more recent terminology of subiectum-praedicatum is the result of a mere metalinguistic shift (cf. Colombat 1999, 394-6; Cser 2000, 30).

Regula II treats the accusativus cum infinitivo construction (cf. Colombat 1999, 513-32; Cser 2001, 27). Chivu's endnote 123 warns the reader, however, that Romanian exhibits no such pattern.

Regulae IV and V discuss the agreement of adjective, pronoun, participle and the accompanying noun (using the term concordant, for instance).

Regula VI mentions the issue of substantiva continuata. This type of construction, known as apposition in more recent grammars (cf. Colombat 1999, 409-10) includes a subtype that deserves special attention as it signals the limits of gender agreement: Romanian Dumnezeu [masc.], veselia mea [fem.] 'God, my joy', Latin Deus [masc.], gaudium meum [neuter] 'id.' (ILVal 69/140). sentiunt".

The point of regula VII is that "interrogatio et responsio casu con-

The agreement rules discussed in regulae I-VII resemble those found in humanistic grammars. The latter invariably involved three types: (1) nominative + verb (person-number agreement); (2) adjective + noun; (3) antecedent + relativum 'relative pronoun' (cf. Colombat 1999, 401).

Regulae VIII-XXII mainly contain rules of government (cf. Colombat 1999, 402, 427-63 - with history-of-terminology and etymological aspects of the terms rectio, regens and their derivatives, terms that have been coming back to use recently). Within government rules of ILVal, regulae VIII-XIX concern verbal syntax, using terms like potest habere; 
casum regunt; admittere potest; "participia ... regunt". Regulae XV-XIX describe nominal syntax, including possessive constructions, government resulting from the comparison of adjectives, etc., using the term jungere ("Adjectiva Comparativi gradus Gen. Plurali junguntur"; "Nomina Adjectiva Dativis junguntur"). This is where the Romanian equivalents of the pronouns suus, sua, suum, as well as ablativus absolutus are also mentioned (with respect to the fate of the latter construction in Romance languages and the relevant - very large - literature, cf. Scaglione 1970; Colombat 1999, 533-54 and passim).

Regula XX concerns locative structures of the $u b i$ 'where', quo 'where to', unde 'where from' types. It also gives examples of adverbial uses of geographical names ("Nomina Propria Regionum, Urbium, Locorum \&c."). Cf. the discussion of Priscianian antecedents of the issue (Le traitement du "Locatif") by Colombat (1999, 444-54). This section of ILVal may be interesting in a non-grammatical sense, too: this is where the following expressions can be read: Fui Constantinopole: in the Modern Romanian translation: "Am fost în Țarigrad"; ${ }^{7}$ Studui Claudiopoli; Profectus sum Varadinum (73-4/144-6).

Regula XXI discusses the government of prepositions (that "diversos Casus admittunt"), while regula XXII treats that of interjections, distinguishing from the latter the word heu, identified as a particle. This is followed by a remark on the two "last" parts of speech: "Adverbia \& Conjunctiones nullos fere casus regunt. Quae vero praepositionibus junguntur [s] uum casum admittunt" (75/146-emphasis mine: R.L.).

The ILVal-Ajtai-Alvares comparison can be extended and given further perspectives by contrasting them with descriptions that predate all the three. For this, a good occasion is presented by the two texts published by András Cser a year before the printed versions of ILVal and his table summarizing historiographic data (Cser 2000, 38-9). The table compares those two texts with two other unpublished manuscripts as well as with a 1486 version of Remigius' Regulae (on Remigius, cf. also Colombat 1999, 377-9; Jensen 2001, 107ff). And what is especially important: the table also contains figures referring to relevant lines of "Doctrinale puerorum", a set of more than 2000 hexameters by the Norman Franciscan, Alexander de Villa Dei (referred to above in connection

\footnotetext{
${ }^{7}$ In certain Slavic languages Constantinople is called Tsarigrad, a loan translation of one of the Greek names of the town Basilis polis [(basilis > caesar $>$ tsar $)+$ (polis $>$ grad)] (cf. Moravcsik 1966, 8-9). This is represented by Romanian Царuгpad, Tarigrad, too.
} 
with Despauterius). This confrontation is also important because Doctrinale was, for a long time, a fundamental textbook and exam material at universities and even from the 16th century the existence of 381 "Western" editions and 2 in Poland can be documented (cf. Jensen 2001, 1077ff; Grubmüller 1983; Cytowska 1968, 103).

As opposed to the morphological table restricted to ILVal and Alvares (1768), the syntactic table below (see Table 2) takes the relevant portions of Alvares (1729) and Ajtai (1744) into consideration as well. Again, it is not difficult to see that, along with the similarities, certain "gaps" and other dissimilarities can be observed.

2.4. Another important issue emerging from the literature on ILVal is that of its authorship.

Chivu mentions one anonymous and two named candidates on the basis of research so far. Gherman, the other publisher of the grammar, considers it to be the work of Grigore Maior (1715-1785). Referring to Tagliavini's data and arguments, Violeta Barbu thinks of the Jesuit Ladislaus Dobra (1720-1784). Also referred to as "Zalathnensis" in the sources, Dobra carried on his work between 1764 and 1767 in Nagyvárad where a brother of his also worked as a teacher from 1767 to 1771 (cf. Lukács 1988, 1: 247; Bunyitay-Málnási 1935, 379; Polgár 1957; 1967). In addition to these possibilities, some other author(s) or contributor(s) can also be assumed to have had a role. According to Szilas' data, the number of native Romanian priests and scholastics among the Jesuits of the Austrian province was 14 (1\% of the total number), plus one brother who spoke fluent Romanian. In addition to Romanian and obviously Latin, all of them spoke further language(s), too (Szilas 1978, 134-6). Chivu likewise assumes an author who was a Jesuit but cannot be identified as yet. Someone whose language use can be related, on the basis of some phonological, morphological, and semantic evidence, with the literary Romanian of Banate, Bihar/Bihor, Southern Transylvania, more exactly, the counties of (Alsó)Fehér/Alba and Hunyad/Hunedoara (Chivu 2001, 22). Of course, he also mentions that some of the geographical names occurring in the examples, especially Claudiopolis (Kolozsvár/Cluj) and Varadinum (see the relevant quotations above) suggest some personal involvement. 


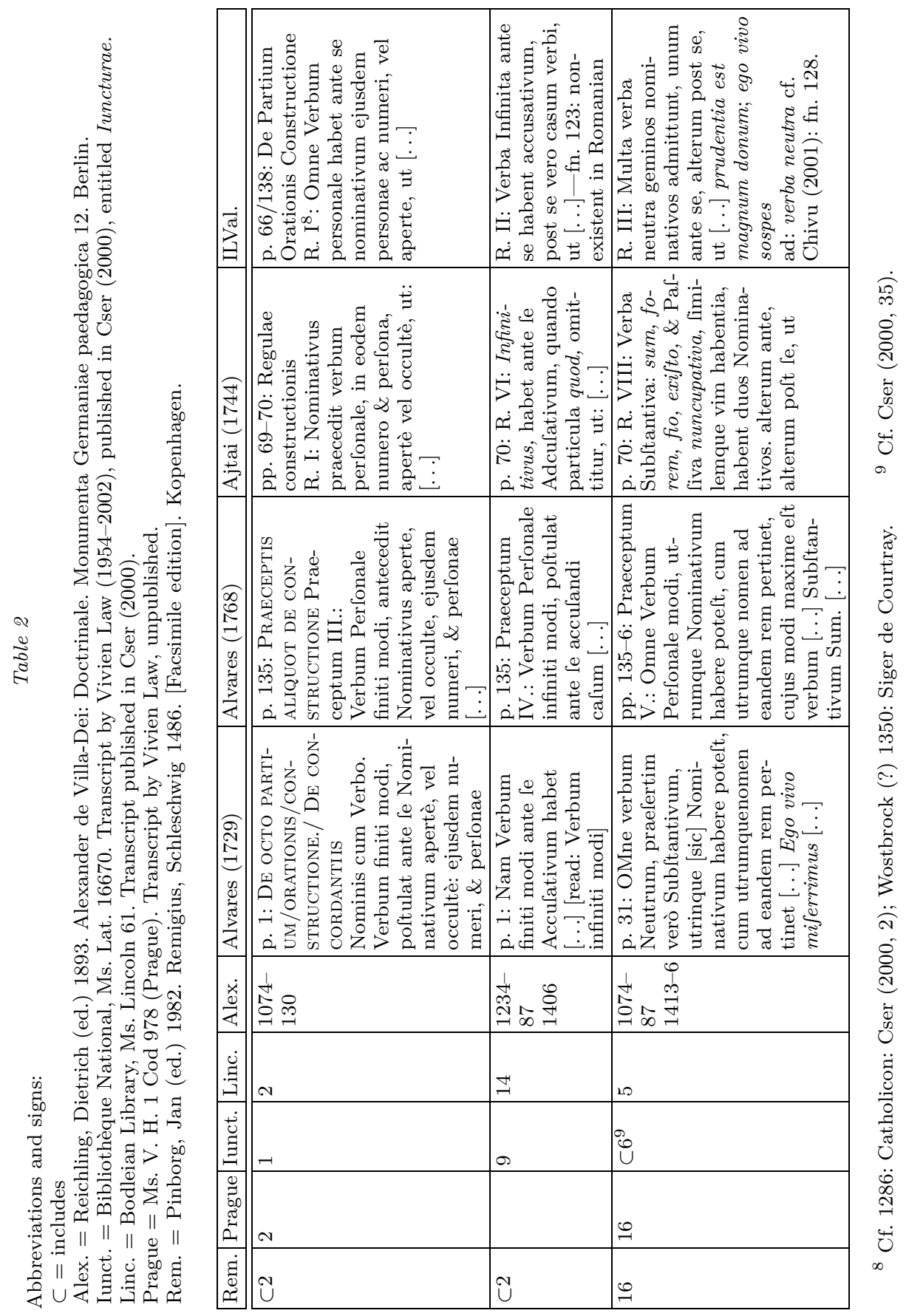

Acta Linguistica Hungarica 56, 2009 


\begin{tabular}{|c|c|c|c|c|}
\hline$\frac{i}{\vec{\pi}}$ & 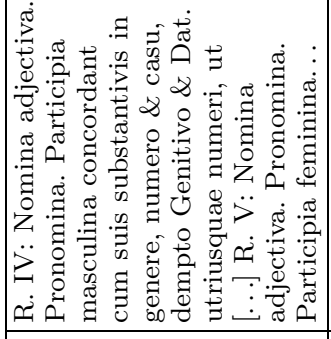 & 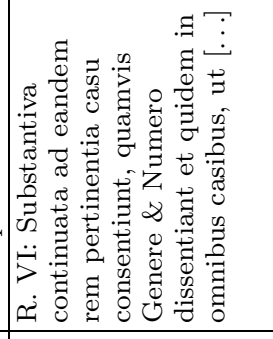 & 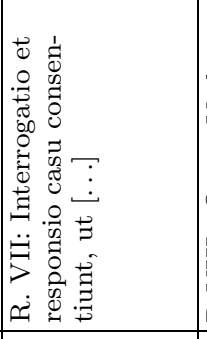 & 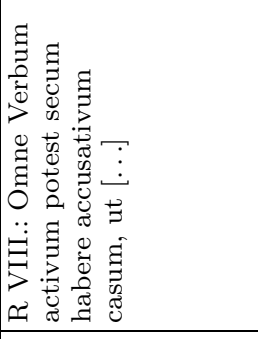 \\
\hline 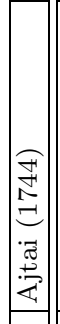 & 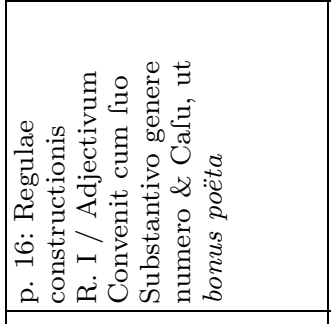 & & 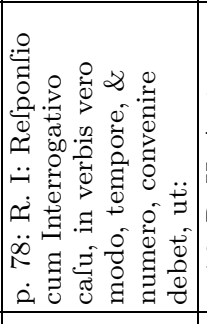 & 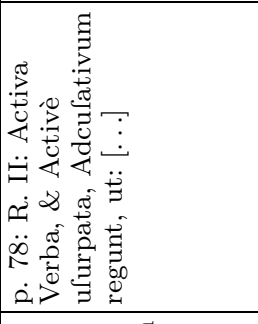 \\
\hline 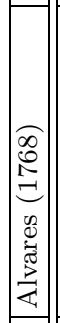 & 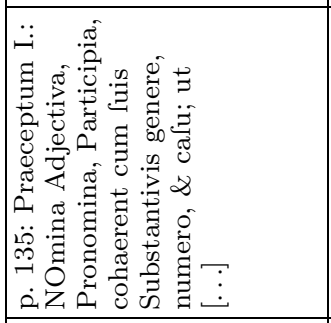 & & 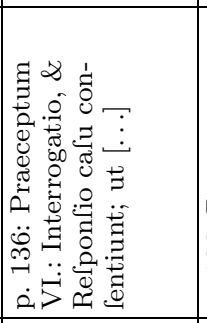 & 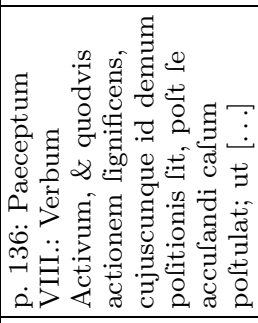 \\
\hline 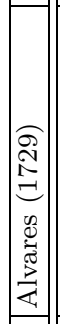 & 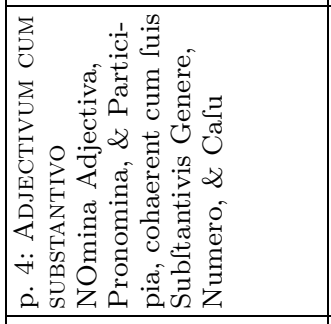 & 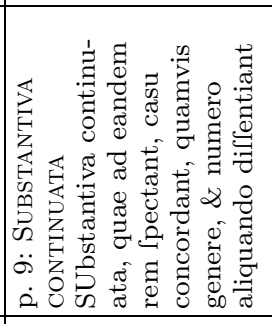 & 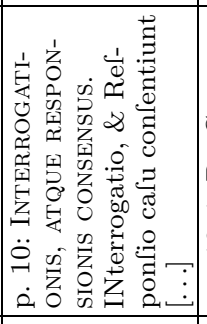 & 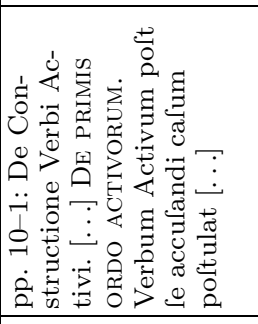 \\
\hline$\frac{\dot{\alpha}}{\stackrel{d}{Q}}$ & 尊 & & $\stackrel{\mathscr{I}}{\underset{I}{~}}$ & 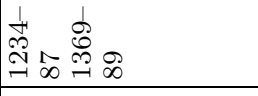 \\
\hline 它 & 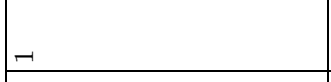 & & $\stackrel{9}{9}$ & $\Im$ \\
\hline 息 & $\curvearrowright$ & & $r$ & $\stackrel{\infty}{\cup}$ \\
\hline . & - & & $\forall$ & \\
\hline 远 & -1 & & $\theta$ & $\stackrel{12}{-1}$ \\
\hline
\end{tabular}

Acta Linguistica Hungarica 56, 2009 


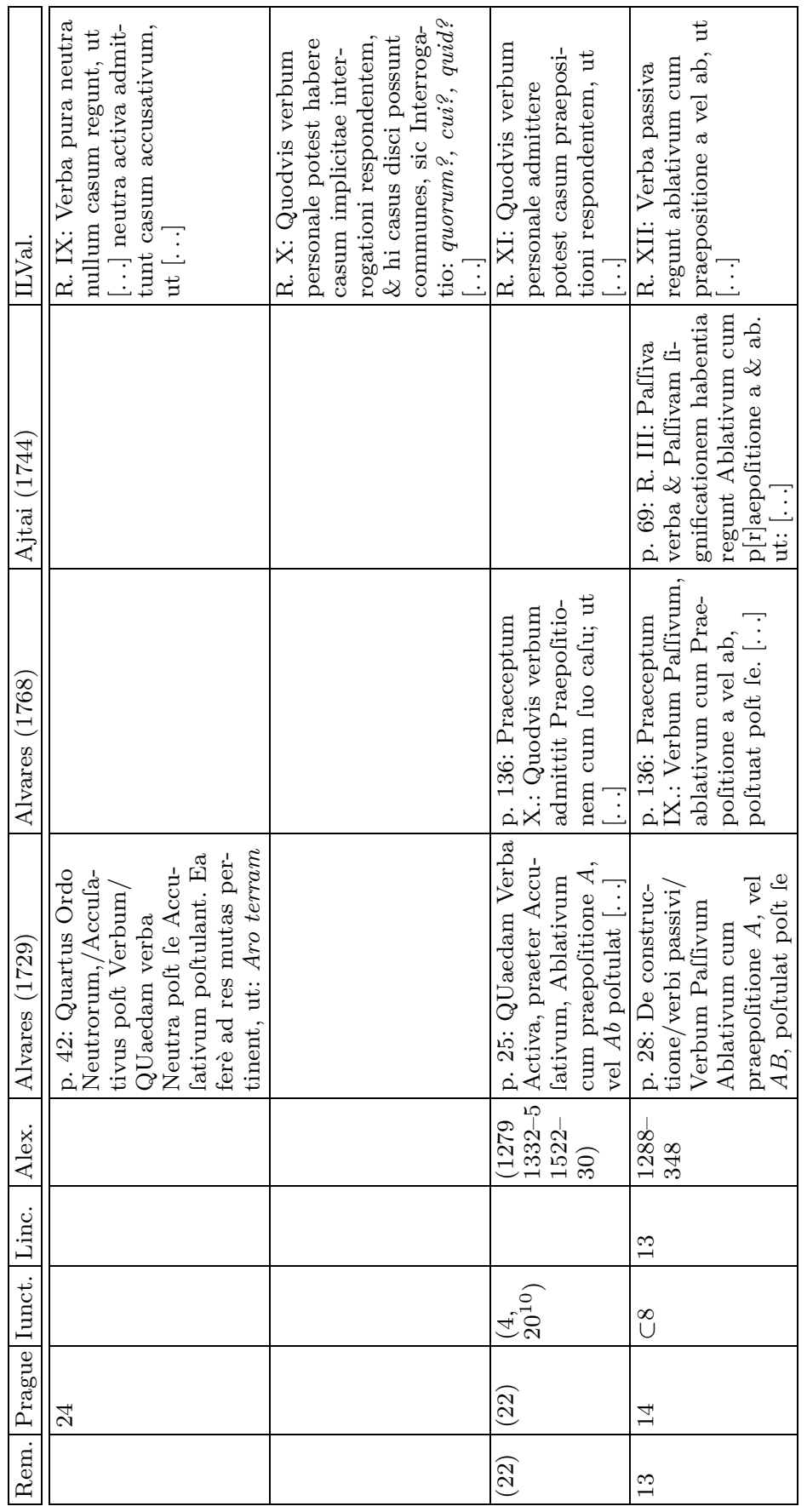

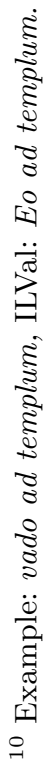




\begin{tabular}{|c|c|c|c|c|}
\hline | & \multirow[t]{2}{*}{ 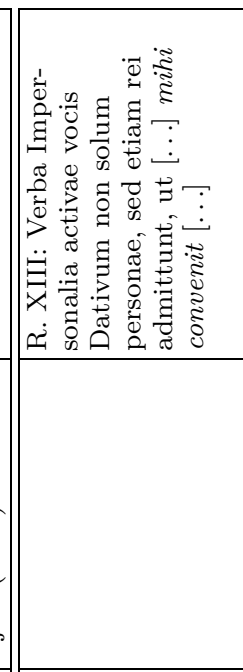 } & \multirow[t]{2}{*}{ 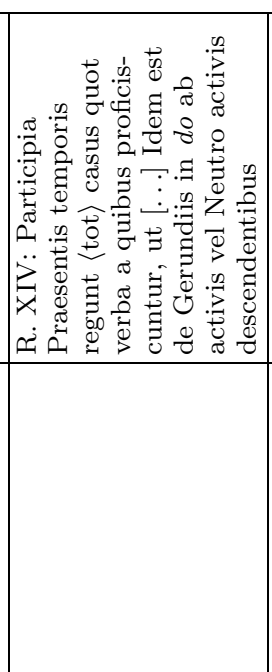 } & 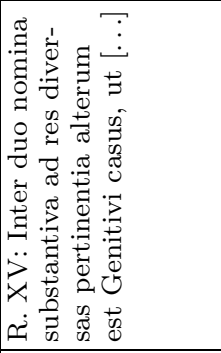 & 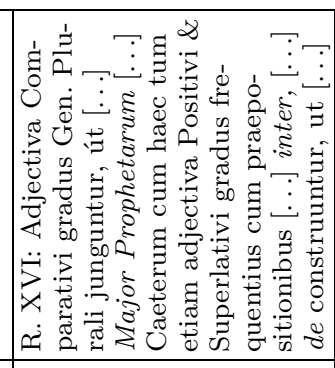 \\
\hline 离) & & & 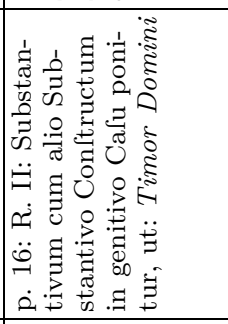 & 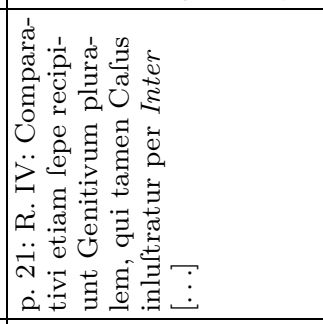 \\
\hline \multicolumn{2}{|c|}{ 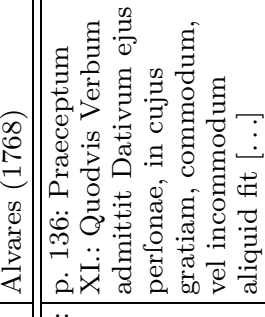 } & 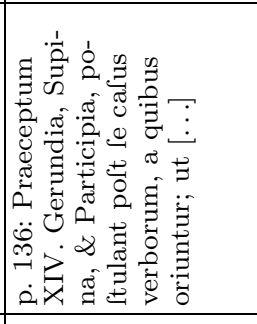 & 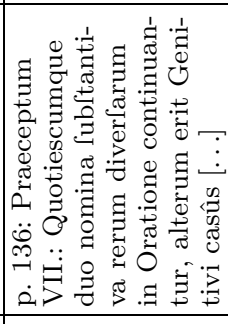 & \\
\hline 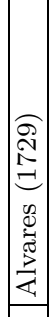 & 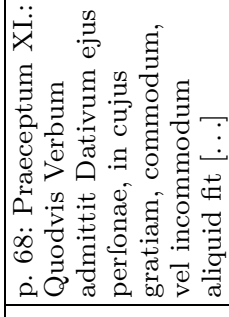 & 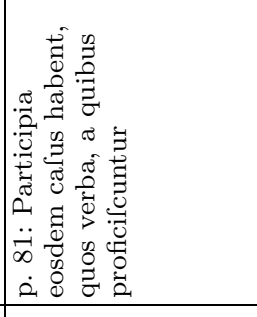 & 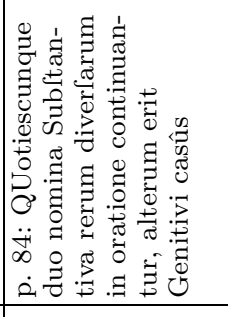 & \\
\hline | & 颃 & & & 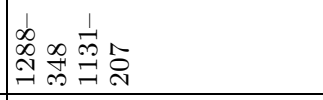 \\
\hline 光 & & $\widehat{\mathbb{d}}$ & $\begin{array}{l}\vec{N} \\
\hat{\sigma} \\
\end{array}$ & \\
\hline$\underline{a}$ & 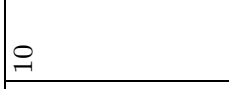 & $\stackrel{20}{U}$ & $\exists$ & $\ddot{U}$ \\
\hline & & $\cong$ & $r$ & $\exists \cong$ \\
\hline & & 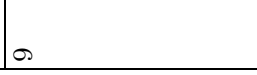 & 0 & $\exists \cong$ \\
\hline
\end{tabular}

Acta Linguistica Hungarica 56, 2009 


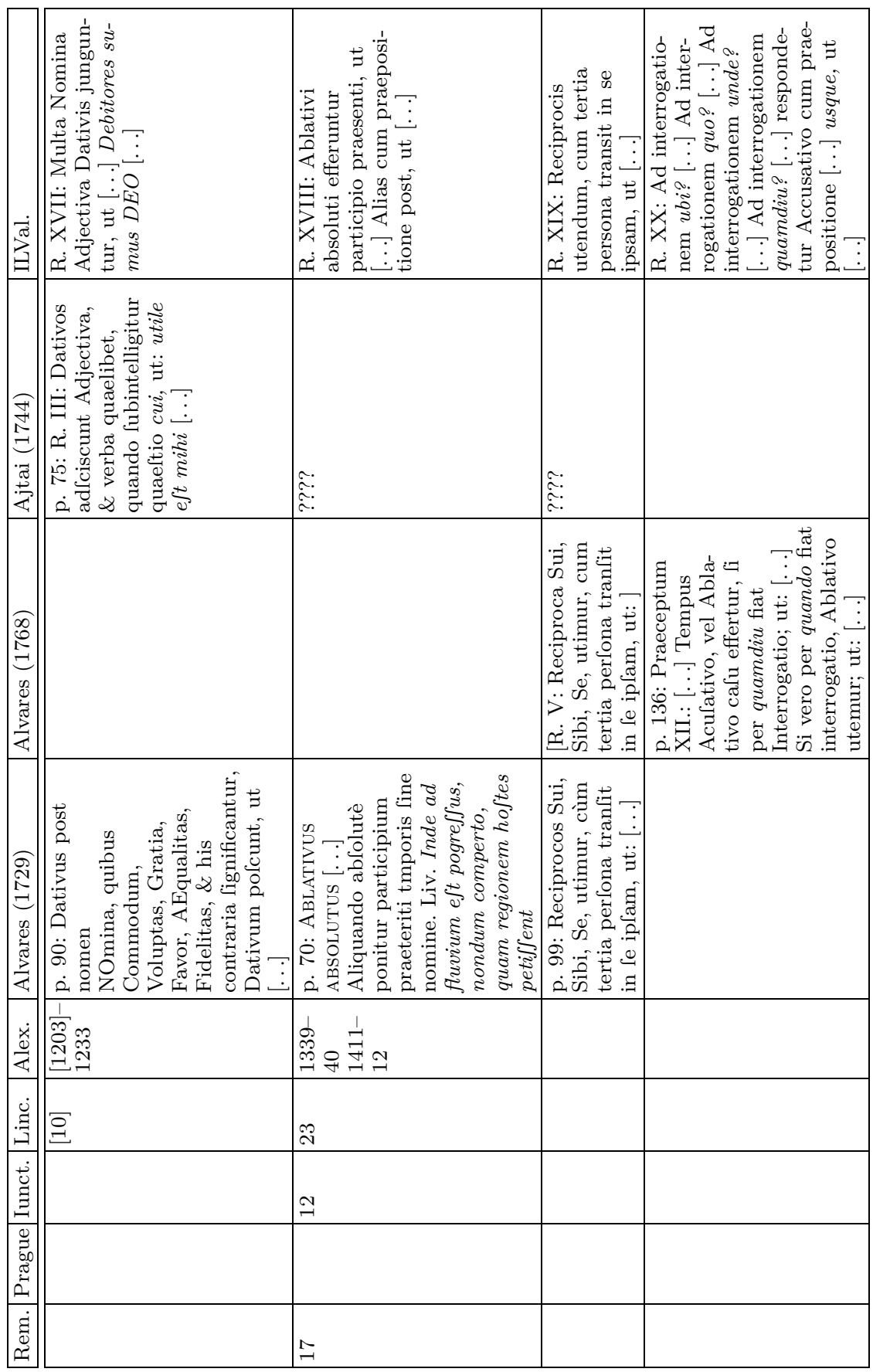




\begin{tabular}{|c|c|c|c|c|}
\hline . & 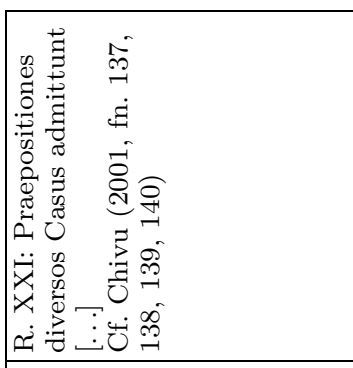 & 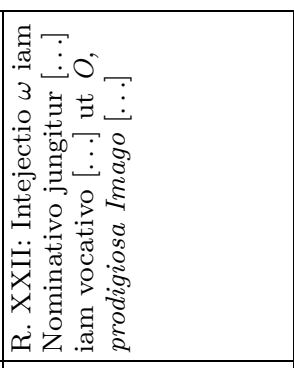 & 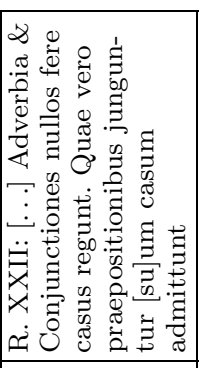 & 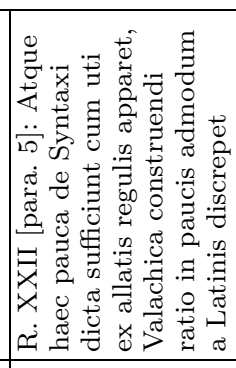 \\
\hline 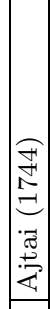 & 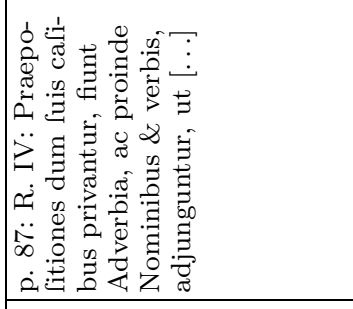 & 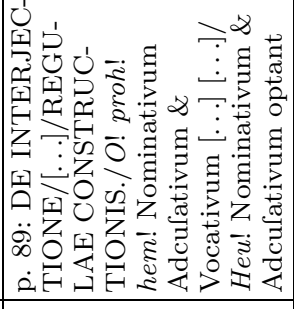 & 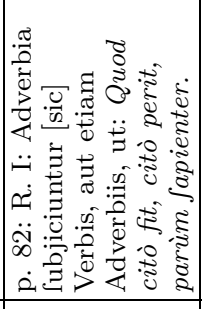 & \\
\hline 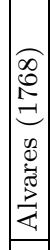 & & & ¿n: & \\
\hline 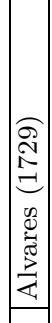 & 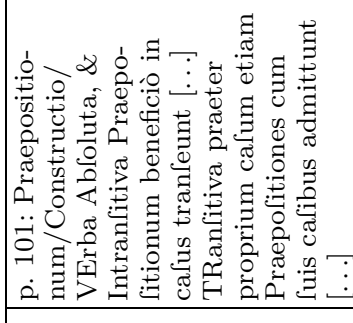 & 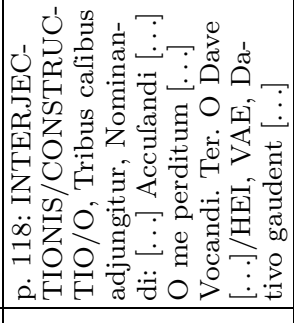 & 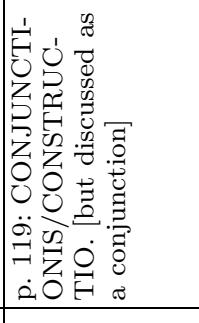 & \\
\hline $\begin{array}{l}\dot{x} \\
\frac{\dot{Q}}{4} \\
\end{array}$ & 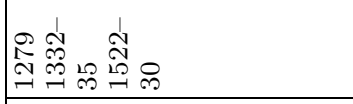 & & 危 & \\
\hline 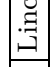 & & & & \\
\hline \begin{tabular}{|l}
$\dot{0}$ \\
$\dot{0}$ \\
$\vdots$ \\
\end{tabular} & 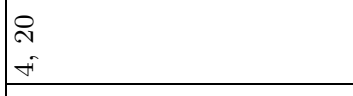 & & & \\
\hline 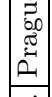 & సิ & 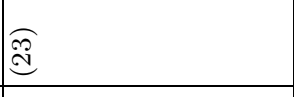 & 10 & \\
\hline | & స̃ & $\stackrel{\leftrightarrow}{N}$ & $\overrightarrow{\tilde{U}} \Re$ & \\
\hline
\end{tabular}

Acta Linguistica Hungarica 56, 2009 
The phrase "studui Claudiopoli" may indeed be informative in this respect; but it would be worth looking into further published and unpublished Jesuit sources. This is suggested, for instance, by the following title (National Széchényi Library 313.225): 1754/1761: Dissertationes /Excerptae /ex /Commentario /Literali /in omnes /Novi Testamenti /Libros /R. P. D. Augustini Calmet, /Ordinis S. Benedicti, Congregationis SS. Vitoni, /\& Hidulphi / tomus secundus /Tyrnaviae, /Typis Academicis Societatis Jesu, /Anno M. DCC. LIV. On the internal title page of the same book: Dum /Assertiones /ex / universa /Philosophia /In Alma, Regioqueprincipali /Universitate /Claudiopolitana /Anno M. DCC. LXI. /mense augusto die. / publice propugnaret. /Nobilis, ac eruditius dominus /Abrahamus Popp /De Oláh-Dallya Natione Valachus. /Philosophiae in Secundum Annum /Auditor /ex /Praelectionibus /R. P. Adami Nyiro /è Soc. Jesu, /AA. LL. \& Philosophiae Doctoris, Ejusdémque /Professoris Publici Ordinarii /Auditoribus Oblatæ /Claudiopoli, /Typis Academicis Soc. Jesu (with respect to the place name Oláhdálya/Daia Română, cf. the entry Székelydálya 'village south-east of Gyulafehérvár [Alba Iulia]' in Kiss 1988).

2.5. The two publishers of ILVal do not go into details concerning the merits of the book as a work of comparative linguistics. Nevertheless, within the context of the history of linguistics in the Carpathian Basin, it is an important piece of work in this respect, too; at least in two senses.

One concerns the professional environment. ILVal, written around 1770, gives expert evidence on the fact that Romanian is a descendant of Latin by way of a systematic presentation of its grammatical structure. Most works written but slightly later also discuss this issue- - but on the basis of a simpler method of language comparison, lexical correspondences. As Éder $(1978,54)$ points out, György Pray (1723-1801) in his "Dissertationes historico-criticae in annales veteres hunnorum, avarum et hungarorum" published in two editions in 1774 in Vienna writes about the descent of Romanian from Latin on the basis of a list of roughly 100 word pairs. According to his source reference (page 15, note s): "Ex Libro, cui titulus: Iftoria delle moderne rivoluzioni de la Valachia-compolita da Antonmaria del Chiaro Fiorentino. In Venezia 1718. a pag. 237" (for references to Chiaro in the Romanian literature on the history of writing, see Vîrtosu 1968, 155). With this in mind, it cannot be mere coincidence that it is in the Pray Collection (University Library Budapest) that the 
manuscript of the 17th-century Romanian dictionary published in 1930 as "Lexicon Marsilianum" (Tagliavini 1930) can be found.

József Benkő (1740-1814) in his "Transsilvania" published in 1778 argues for the Latin origin of Romanian with a self-compiled word list (Éder 1978, 52-4). The following lines of another book of his, written in 17911792 (A' magyar és török nyelv mely keveset egyezzen [...]. Bévezetés [...] [The little correspondence between Hungarian and Turkish. Introduction] $\S$. I. 7: published in: Éder 1978, 149-214) witness his thinking in terms of a language family: "[a' Római nyelvből], mely is néhányféle fzóllások módjára ágazván; főképpen az idegen Nemzetekkel való megelegyedés és küllő fzók bévétele miatt: [...] támadtanak az Olafzok vagy Táliánok, Frantziák, Spanyorok [!: Éder] és némely más atyafias Nemzetek; melyek közzül valóknak lenni tartják magokat az Oláhok avagy Romunok is: kiknek nyelvek az Olafzokéval legatyafiságosabb" [. . f from the language of Rome that branched into several kinds of dialects, mainly due to mixing with foreign nations and the borrowing of external words, have descended the Italians, the French, the Spanish, and some other related nations, one of which the Romanians also take themselves to be: whose language is the most closely related to that of the Italians] (Éder 1978: 157). As Éder (1978, 36-7) mentions, Benkő refers to Josephus Justus Scaliger (15401609) already in 1760. Scaliger in his "Diatriba de Europaeorum linguis" (1599/1610) draws important conclusions with respect to the relatedness of Latin and the Romance languages. With respect to later comparative work on Latin and Romanian by Pál Beregszászi Nagy (around 17501828), István Sándor (1750-1815) and others, see the seminal paper by László Gáldi (1910-1974) (Gáldi 1958).

Secondly, as to the origin of Romanian, ILVal makes two definite statements in two structurally prominent passages. One of these statements is made in the Praefatio. This, in fact, can be understood as the programmatic key sentence of the whole work: "Utque harum Institutionum utilitas ad plures pertineret, Methodo Latinae Linguae convenienti, cui Valachicum hoc Idioma sua debet cunabula /pertractandas existimavi". The other locus is the last paragraph of the last regula (XXII) where the author writes as a final conclusion: "Atque haec pauca de Syntaxi dicta sufficiunt cum uti ex allatis regulis apparet, Valachica construendi ratio in paucis admodum a Latinis discrepet" (76/146).

In conclusion, the twenty-first-century reader has all reasons to suggest the following claims: (1) Beside (perhaps even before) the celebrated Demonstratio (1770) by János Sajnovics (1733-1785), known as the ear- 
liest work in comparative linguistics, ILVal is an essential early document of that discipline. (2) In relation to an important member of the Romance languages, it is definitely the first extant comparative grammar in the history of Romance philology in the Carpathian Basin.

3. Returning finally to some issues mentioned at the beginning of this paper: As far as internal matters of Romanian grammar raised by ILVal are concerned, it is obviously experts in Romanian descriptive linguistics who are competent to evaluate them. However, with respect to issues that go beyond the description of Romanian, an outsider is perhaps also entitled to her opinion, as follows:

(1) In accordance with what the Praefatio says (see above), the work indeed follows a descriptive method suited to Latin. This sentence of ILVal can be made more contentful by recognising that the methodus in question means the procedure of describing Latin followed by Alvares.

(2) Some components of the Alvares-ILVal model can be traced back at least to medieval Latin grammars.

(3) Scholars of the comparative history of grammar writing may be interested in our conclusion that, presumably independently of Alvares, other humanistic grammars (little studied so far), including Rhenius' textbooks also used in these parts, Ajtai's grammar, etc., also work with somewhat similar methods.

(4) It may be a further point of interest, and not merely for the history of Hungarian grammar writing, that the humanistic methods (not independent of much earlier predecessors) crop up, in addition to works on Latin itself, in a well-defined group of vernacular grammars written in Latin, those describing the Hungarian language.

\section{Sources}

Ajtai Abód, Mihály 1744. Grammatica Latina Methodo Nova \& artificiofa In Ufum Inlustris Gymnafii Bethleniani adornata. Apud Johannen Barth, Cibinii.

Alvares, Emmanuel 1729. [D]e Institutione Grammatica Liber Secundus, Ad Veterum ferè Grammaticorum Rationem revocatus. De Constructione Octo Partium Orationis. Typis Acad. Soc. Jesu, Claudiopoli.

Alvares, Emmanuel 1768. Principia seu Rudimenta Grammatices, ex Institutionibus Emmanuelis Alvari è Societate Jesu. Liber Primus. Typis Academicis Soc. Jesu, Claudiopoli. 
Arnauld, Antoine-Claude Lancelot 1676/1966. Grammaire générale et raisonnée ou La Grammaire de Port-Royal. Edition critique présentée par Herbert E. Brekle. Nouvelle impression en facsimilé de la troisième édition de Fridrich Frommann Verlag (Günther Holzboog). Stuttgart \& Bad Cannstatt, 1966.

Chivu, Gheorghe (ed., introd., notes) 2001. Institutiones linguae valachicae. Prima gramatică a limbii române scrisă în limba latină. Ediție critică de Gheorghe Chivu. Revizia şi traducerea textului latin de Lucia Wald. Academia Română Institutul de Lingvistică "Iorgu Iordan". Editura Academiei Române, Bucureşti.

Cser, András (ed.) 2000. Viginti quatuor sunt iuncturae. A Medieval Latin grammatical text with translation and a critical study. Pázmány Péter Katolikus Egyetem Bölcsészettudományi Kar, Piliscsaba.

Gherman, Alin-Mihai (ed., introd., notes) - Iacob Mârza (foreword and summary) 2001. Grigore Maior: Institutiones Lingvae Valachicae. Lexicon Compendiarium LatinoValachicum. Bibliotheca Universitatis Apulensis, Alba Iulia.

Komáromi Csipkés, György 1655. Hungaria Illustrata. [...] Ultrajecti. Reprinted in: Toldy $(1866,331-402)$.

Kövesdi, Pál 1686. Elementa Linguae Hungaricae. Samuel Brewer, Leutschoviae. Reprinted in: Toldy $(1866,549-84)$.

Lőrinczi, Réka (ed.) 1998. Kéziratos magyar nyelvtanok [Hungarian manuscript grammars]: Kolozsvári Grammatika, Fejérvári Sámuel: Institutiones. A Magyar Nyelvtörténet Forrásai. 3. Budapest.

Pereszlényi, Pál 1682. Grammatica Lingvae Vngaricae. Tyrnaviae. Reprinted in: Toldy (1866, 403-548).

Schönvisner, István [before 1818] Vita Georgii Pray. Manuscript, National Széchényi Library, Fol. Lat. 3: 8.

Sylvester, János 1539. Gramatica Hungarolatina in usum pueroru recens scripta Ioanne Sylvestro Pannonio autore. Neansi [Sárvárújsziget]. Reprinted in: Toldy (1866, $1-78)$.

Szenczi Molnár, Albert 1610. Novae Grammaticae Vngaricae succinta Methodo comprehensae, et perspicius exemplis illustratae Libri duo. Hanovaiae. Reprinted in: Toldy $(1866,115-220)$.

Tagliavini, Carlo 1930. Il "Lexicon Marsilianum". Dizionario latino-rumeno-ungherese del sec. XVII. Studio Filologico e testo. Academia Română. Etudes et recherches. V. Cvltvra Națională, Bucureşti.

Toldy, Ferencz (ed.) 1866. Corpus grammaticorvm lingvae Hungaricae veterum. A régi magyar nyelvészek Erdősitől Tsétsiig [Early Hungarian linguists from Sylvester to Tsétsi]. Pest.

\section{References}

Ax, Wolfram (ed.) 2001. Von Eleganz und Barberei. Lateinische Grammatik und Stilistik in Renaissance und Barock. Wolfenbüttler Forschungen 95. Harrassowitz Verlag, Wiesbaden.

Acta Linguistica Hungarica 56, 2009 
Balázs, János 1958. Zur Frage der Typologie europäischer Schriftsysteme mit lateinischen Buchstaben. In: Studia Slavica 4: 251-92.

Bauer, Barbara 1998. Deutsch und Latein in den Schulen der Jesuiten. In: Guthmüller (1998, 227-59).

Borsa, Gedeon - Ferenc Hervay - Béla Holl - István Käfer - Ákos Kelecsényi (eds) 1971. Régi magyarországi nyomtatványok [Early Hungarian prints]. 1473-1600. Akadémiai Kiadó, Budapest.

Breitschneider, Gunther-Christian Lehmann (eds) 1980. Wege zur Universalienforschung. Narr, Tübingen.

Bunyitay, Vince-Ödön Málnási 1935. A váradi püspökség története alapításától a jelenkorig [The history of the Episcopate of Nagyvárad from its foundation to the present]. Vol. 4.: A váradi püspökök a számüzetés és az újraalapítás korában [Bishops of Nagyvárad in the age of exile and refoundation]. 1566-1780. [s.n.], Debrecen.

Coseriu, Eugenio 1980. Partikeln und Sprachtypen. Zur strukturell-funktionellen Fragestellung in der Sprachtypologie. In: Brettschneider-Lehmann (1980, 199-206).

Colombat, Bernard 1999. La grammaire latine en France à la Renaissance et à l'Âge classique. Théories et pedagogie. ELLUG Université Stendhal, Grenoble.

Cytowska, Maria 1968. Od Aleksandra do Alwara. (Gramatyki Łacińskie w Polsce w XVI. W.). Komitet Nauk O Kulturze Antycznej Polskiej Akademii Nauk. Archiwum Filologiczne [...] 18. Zakład Narodowy Imiena Ossołińskich. Wydawnictwo Polskiej Akademii Nauk, Wrocław-Warszawa-Kraków.

Cséplő, Péter 1894. A nagyváradi r. kath. főgymnásium története [The history of the Roman Catholic Secondary School in Nagyvárad I.]. In: A Jászóvári Prémontrei kanonokrend Nagyváradi Főgimnáziumának Értesítője: 3-56. [s.n.], Nagyvárad.

Cséplő, Péter 1895. A nagyváradi r. kath. főgymnásium története [The history of the Roman Catholic Secondary School in Nagyvárad II.]. In: A Jászóvári Prémontrei kanonokrend Nagyváradi Főgimnáziumának Értesítője: 3-87. [s.n.], Nagyvárad.

Dascal, Marcelo 1990. Leibniz on Particles: Linguistic form and comparatism. In: de Mauro-Formigari (1990, 31-61).

Éder, Zoltán 1978. Benkő József nyelvészeti munkássága és az Erdélyi Magyar Nyelvművelö Társaság [The linguistic oeuvre of József Benkő and the Transylvanian Hungarian Society for Language Cultivation]. Akadémiai Kiadó, Budapest.

Emődi, András 2002. A nagyváradi székeskáptalan könyvtára a XVIII. században [The library of the Nagyvárad Cathedral Chapter in the 18th century]. A Kárpátmedence Kora Újkori Könyvtárai V. Országos Széchényi Könyvtár-Scriptum, Budapest \& Szeged.

Gáldi, László 1958. Contributions hongroises à la découverte de la langue roumaine. In: Acta Linguistica Hungarica 7: 1-38.

Grubmüller, Klaus 1983. Der Lehrgang des Triviums und die Rolle der Volkssprache im späten Mittelalter. In: Moeller et al. (1983, 371-97).

Guthmüller, Bodo (ed.) 1998. Latein und Nationalsprachen in der Renaissance. Wolfenbütteler Abhandlungen zur Renaissanceforschung. In Zusammenarbeit mit dem Wolfenbütteler Arbeitskreis für Renaissanceforschung. Herausgegeben von der Herzog August Bibliothek. Band 17. Harrassowitz Verlag, Wiesbaden. 
Hets, Aurelián O. S. B. 1938. A jezsuiták iskolái Magyarországon a 18. század közepén [Jesuits' schools in Hungary in the mid-18th century]. Publicationes ad Historiam S. J. in Hungaria Illustrandam. Lucubrationes [...], Pannonhalma.

Jakó, Klára 1991. Az első kolozsvári egyetemi könyvtár története és állományának rekonstrukciója [The history of the first university library of Kolozsvár and the reconstruction of its inventory]. 1579-1604. Erdélyi Könyvesházak I. Bálint Keserü (ed.): Adattár XVI-XVIII. századi szellemi mozgalmaink történetéhez. 16/1. Scriptum, Szeged.

Jensen, Kristian 2001. Elementary Latin grammars printed in the fifteenth century: Patterns of continuity and of change. In: Ax (2001, 103-25).

Kese, Katalin 1999. Kultúra és filológia a Román Tanszék történetének tükrében [Culture and philology in the history of the Department of Romanian]. Fejezetek az Eötvös Loránd Tudományegyetem Történetéből 19. Eötvös Loránd Tudományegyetem Levéltára, Budapest.

Kiss, Lajos 1988. Földrajzi nevek etimológiai szótára [An etymological dictionary of geographical names]. Akadémiai Kiadó, Budapest.

Kniezsa, Isvtán 1952. A magyar helyesírás története [The history of Hungarian orthography]. Egyetemi Magyar Nyelvészeti Füzetek. Tankönyvkiadó, Budapest.

Laczkó, Krisztina (ed.) 1995. Emlékkönyv Szathmári István hetvenedik születésnapjára [A Festschrift for István Szathmári on his seventieth birthday]. ELTE BTK Mai Magyar Nyelvi Tanszéke, Budapest.

Lallot, Jean 1998. La grammaire de Denys le Thrace. Traduite et annotée par Jean Lallot. 2ième éd. CNRS Editions, Paris.

Landgraf, Gustav (ed.) 1903. Historische Grammatik der lateinischen Sprache. Tom. III. Teubner, Leipzig.

Law, Vivien 1986. Late Latin grammars in the Early Middle Ages. A typological history. In: Historiographia Linguistica 13: 365-79.

Lischerong, Gáspár S. I. 1937. Pray György élete és munkái [György Pray's life and work] (Publicationes ad Historiam Soc. Jesu in Hungaria Illustrandam - Kiadványok Jézus Társasága Magyarországi Történetéhez. Lucubrationes-Tanulmányok 4.) Pray Rendtörténetíró Munkaközösség, Budapest.

Lőrinczi, Réka 1995. Ha a magyar nyelvet felsőbb fokon (is még) írni kezdik [If Hungarian begins to be written at a higher level (as well)]. In: Laczkó (1995, 272-7).

Lőrinczi, Réka 2005a. Egy XVIII. századi román nyelvtanhoz kapcsolódó nyelvleírástörténeti észrevételek [Observations on the history of linguistic description apropos of an 18th-century Romanian grammar]. In: Magyar Nyelv 101: 65-73.

Lőrinczi, Réka 2005b. További észrevételek egy XVIII. századi román nyelvtanhoz [Further observations on an 18th-century Romanian grammar]. In: Magyar Nyelv 101: 221-32

Lukács, Ladislaus (ed.) 1986. Monumenta Paedagogica Societatis Iesu. Ratio atque institutio studiorum Societatis Iesu $(1586,1591,1599)$. V. Monumenta Historica Societatis Iesu A Patribus Eiusdem Societatis Edita Volumen 129. Institutum Historicum S. I., Roma.

Lukács, Ladislaus S. I. 1988. Catalogus generalis seu Nomenclator biographicus personarum Provinciae Austriae Societatis Iesu (1551-1773). Institutum Historicum S. I., Roma.

Acta Linguistica Hungarica 56, 2009 
Lukács, Ladislaus (ed.) 1992. Monumenta Paedagogica Societatis Iesu. Collectanea de Ratione Studiorum Societatis Iesu (1588-1616). VII. Monumenta Historica Societatis Iesu A Patribus Eiusdem Societatis Edita Volumen 141. Institutum Historicum S. I., Roma.

Mauro, Tullio de-Lia Formigari (eds) 1990. Leibniz, Humboldt, and the origins of comparativism. Proceedings of the international conference. Rome, 25-28 September 1986. Amsterdam Studies in the Theory and History of Linguistic Science. Series III: Studies in the History of Language Sciences 49. Benjamins, Amsterdam \& Philadelphia.

Mátai, Mária D. 1992. A magyar nyelvet írni kezdik [The Hungarian language begins to be written]. In: Magyar Nyelv 88: 56-72.

Mălinaş, Ioan Marin 1997. Bizanț, Roma, Viena şi fenomenul uniatist. Editura "Mihai Eminescu", Oradea \& Vienna.

Mészáros István 1981. Az iskolaügy története Magyarországon 996-1777 között [The history of schooling in Hungary between 996 and 1777]. Akadémiai Kiadó, Budapest.

Moeller, Bernd-Hans Patze-Karl Stackmann (eds) 1983. Studien zum städtischen Bildungswesen des späten Mittelalters und der frühen Neuzeit. Bericht über Kolloquien der Komission zur Erforschung der Kultur des Spätmittelalters. 1978 bis 1981. Abhandlungen der Akademie der Wissenschaften in Göttingen. Philologisch-Historische Klasse. Nr. 137. Vandenhoeck \& Ruprecht, Göttingen.

Molnár, Antal 1999. A Jezsuita misszió Karánsebesen [The Jesuit mission in Karánsebes] (1625-1642). In: Történelmi Szemle 41: 127-56.

Moravcsik, Gyula 1966. Bevezetés a bizantinológiába [Introduction to Byzantinology]. Tankönyvkiadó, Budapest.

Nagy, Béla 1983. Les manuscrits Roumains de Kalocsa (Fragment d'une étude plus longue). In: Annales Universitatis Scientiarum Budapestinensis de Rolando Eötvös Nominatae. Sectio Linguistica 14: 201-17.

Nagy, Béla 1984a. A Kalocsai román nyelvtan [The Romanian grammar of Kalocsa]. In: Nagy (1984b: 409-20).

Nagy, Béla (ed.) 1984b. Magyar-román filológiai tanulmányok [Studies in HungarianRomanian philology]. ELTE Román Filológiai Tanszék, Budapest.

Nagy, Levente 2000. Bethlen Miklós „ezer vagy kétezer szavas” latin-román-magyar szójegyzéke [Miklós Bethlen's Latin-Romanian-Hungarian glossary "of a thousand or two thousand words"]. In: Magyar Nyelv 91: 332-42.

Nägler, Doina 1982. Catalogul transilvanicelor II. Biblioteca Muzeului Brukenthal, Sibiu.

Periş, Lucian 1998. Le Missioni Gesuite in Transilvania e Moldavia nel Seicento. Editura Fundației pentru Studii Europene, Cluj-Napoca.

Polgár, Ladislaus 1957. Bibliographia de historia Societatis Iesu in Regnis olim Corona Hungarica unitis (1560-1773). Institutum Historicum S. I., Roma.

Polgár, Ladislaus 1967. Bibiliography of the History of the Society of Jesus. [. . . ] Sources and Studies for the History of the Jesuits Volume I. Institutum Historicum S. I., Roma. 
Sára, Balázs 1999-2001. Quid est grammatica?-cuius est grammatica? In: Annales Universitatis Scientiarum Budapestinensis de Rolando Eötvös Nominatae. Sectio Linguistica $24: 159-81$.

Scaglione, Aldo 1970. Ars grammatica. A bibliographic survey, two essays on the grammar of the Latin and Italian subjunctive, and a note on the ablative absolute. Janua Linguarum. Studia memoriae Nicolai van Wijk dedicata edenda curat C. H. van Schooneveld, Indiana University. Series Minor 77. Mouton, The Hague \& Paris.

Schäffer-Priess, Barbara 2000. Die portugiesische Grammatikschreibung von 1540 bis 1822. Entstehungsbedingungen und Kategorisierungsverfahren vor dem Hintergrund der lateinischen, spanischen und französischen Tradition (Beihefte zur Zeitschrift für Romanische Philologie. [...] Band 300.) Niemeyer, Tübingen.

Schenkeveld, D. M. 1988. From particula to particle. The genesis of a class of words. In: Irène Rosier (ed.) L'héritage des grammairiens latins de l'Antiquité aux Lumières. Actes du Colloque de Chantilly 2-4 septembre 1987: 81-93. Bibliothèque de l'Information Grammaticale (BIG), Paris.

Sommervogel, Carlos S. J. 1890-1909. Bibliothèque de la Compagnie de Jésus [...]. Oscar Schepens; Alphonse Picard; Libraire Alphonse Picard et Fils. Bruxelles \& Paris.

Springhetti, Emilio S. J. 1961-1962. Storia e fortuna della Grammatica di Emmanuele Alvares. In: Humanitas 13-14: 283-304. Coimbra.

Szabó, Károly 1879-1898. Régi magyar könyvtár [Early Hungarian library]. I-III/1. Budapest.

Szilas, László 1978. Die österreichische Jesuitenprovinz in Jahre 1773. In: Archivum Historicum Societatis Iesu 57: 93. fasc.: 97-158. Roma.

Vértes, O. András 1980. A magyar leíró hangtan története az újgrammatikusokig [The history of Hungarian descriptive phonology to the age of the Neogrammarians]. Akadémiai Kiadó, Budapest.

Vîrtosu, Emil 1968. Paleografia româno-chirilică. Editura Ştiințifică, Bucureşti.

Zwartjes, Otto 2002. The description of the indigenous languages of Portuguese America by the Jesuits during the Colonial Period. The impact of the Latin grammar of Manuel Álvares. In: Historiographia Linguistica 29: 19-70. 